\title{
Management of cutaneous T cell lymphoma: new and emerging targets and treatment options
}

\author{
This article was published in the following Dove Press journal: \\ Cancer Management and Research \\ 9 March 2012 \\ Number of times this article has been viewed
}

\author{
Janet $\mathrm{Y} \mathrm{Li}^{\prime}$ \\ Steven Horwitz ${ }^{2}$ \\ Alison Moskowitz ${ }^{2}$ \\ Patricia L Myskowski ${ }^{3}$ \\ Melissa Pulitzer ${ }^{4}$ \\ Christiane Querfeld ${ }^{3}$ \\ 'College of Physicians and Surgeons, \\ Columbia University, ${ }^{2}$ Department \\ of Medicine, Lymphoma Service, \\ ${ }^{3}$ Department of Medicine, \\ Dermatology Service, ${ }^{4}$ Department \\ of Pathology, Memorial Sloan \\ Kettering Cancer Center, \\ New York, NY, USA
}

Correspondence: Christiane Querfeld Department of Medicine, Dermatology Service, Memorial Sloan Kettering Cancer Center, 160 East 53rd Street, New York, NY 10022, USA

$\mathrm{Tel}+\mid 212610078$ I

$\mathrm{Fax}+\mathrm{I} 2123080739$

Email querfelc@mskcc.org

\begin{abstract}
Cutaneous T cell lymphomas (CTCL) clinically and biologically represent a heterogeneous group of non-Hodgkin lymphomas, with mycosis fungoides and Sézary syndrome being the most common subtypes. Over the last decade, new immunological and molecular pathways have been identified that not only influence CTCL phenotype and growth, but also provide targets for therapies and prognostication. This review will focus on recent advances in the development of therapeutic agents, including bortezomib, the histone deacetylase inhibitors (vorinostat and romidepsin), and pralatrexate in CTCL.
\end{abstract}

Keywords: novel targets, histone deacetylase inhibitors, pralatrexate, bortezomib, cutaneous $\mathrm{T}$ cell lymphoma

\section{Introduction}

Cutaneous T cell lymphomas (CTCL) represent a heterogeneous group of non-Hodgkin lymphomas characterized by an initial infiltration of the skin with clonally-derived malignant T lymphocytes of the CD4+ CD45RO+ phenotype that generally lack normal T cell markers, such as CD7 and CD26. ${ }^{1}$ The diversity of clinical and pathologic manifestations among subsets of CTCL has led to much controversy over its diagnosis and classification and to the establishment of consensus guidelines by a joint effort of the World Health Organization and European Organization for Research and Treatment of Cancer (WHO-EORTC) in 2005. ${ }^{2}$

The two most common types of CTCL are mycosis fungoides $(50 \%-72 \%)$, which is generally indolent in behavior, and Sézary syndrome (1\%-3\%), an aggressive leukemic form of the disease (Table 1$).^{2-5}$ Other types include primary cutaneous CD30+ lymphoproliferative disorders, subcutaneous panniculitis-like T cell lymphoma, and the group of primary cutaneous peripheral $\mathrm{T}$ cell lymphomas that includes the provisional entities of cutaneous aggressive epidermotropic CD $8^{+} \mathrm{T}$ cell lymphoma, cutaneous $\gamma / \delta \mathrm{T}$ cell lymphoma, and cutaneous $\mathrm{CD}^{+}{ }^{+}$small/medium-sized pleomorphic T cell lymphoma., ${ }^{4,6}$

Mycosis fungoides and Sézary syndrome together comprise $54 \%$ of all CTCL. ${ }^{2}$ The annual incidence of CTCL in the United States has increased from 2.8 per million (19731977) to 9.6 per million (1998-2002) according to data from Criscione and Weinstock. ${ }^{5}$ Median age at presentation is between 50 and 70 years, ${ }^{5,7,8}$ although pediatric and young adult cases do occur. ${ }^{9,10}$ Mycosis fungoides classically presents with an indolent course and slow progression over years or sometimes decades. The disease may evolve from patches to infiltrated plaques and eventually to tumors (Figure $1 \mathrm{~A}$ and B). However, about $30 \%$ of 
Table I European Organization for Research and Treatment of Cancer consensus classification for primary cutaneous lymphomas with relative frequency and 5-year survival

\begin{tabular}{lll}
\hline WHO-EORTC & Frequency & 5 -year survival \\
& $(\%)$ & $(\%)$ \\
\hline
\end{tabular}

Cutaneous $\mathbf{T}$ cell and natural killer cell lymphoma Indolent

Mycosis fungoides

Follicular mycosis fungoides

- Pagetoid reticulosis

44

4

$<$ I

$<1$

8

- Anaplastic large cell

lymphoma

- Lymphomatoid papulosis

Subcutaneous panniculitis-

like $T$ cell lymphoma

CD4 ${ }^{+}$small/medium

pleomorphic $T$ cell lymphoma

\section{Aggressive}

\section{Sézary syndrome}

Cutaneous peripheral T cell

lymphoma, unspecified

- Cutaneous aggressive CD8+ T cell lymphoma

- Cutaneous $\gamma / \delta$ T cell lymphoma

Cutaneous natural killer/

T cell lymphoma, nasal-type

Cutaneous B cell lymphoma

Indolent

Follicle center cell lymphoma

Marginal zone lymphoma

Intermediate clinical behavior

Large B cell lymphoma

of the leg

Cutaneous diffuse large

B cell lymphoma, other

Intravascular large

B cell lymphoma

Copyright (c) 2005, American Society of Hematology. Adapted with permission from Willemze R, Jaffe ES, Burg G, et al. WHO-EORTC classification for cutaneous lymphomas. Blood. 2005; 105(10):3768-3785.

Abbreviations: WHO, World Health Organization; EORTC, European Organization for Research and Treatment of Cancer.

patients present with skin tumors (T3) or erythroderma (T4) at initial presentation. ${ }^{8}$ Sézary syndrome is a much more aggressive disease. Patients with Sézary syndrome present with erythroderma, circulating malignant T cells (Sézary cells), and severe disabling pruritus with or without associated lymphadenopathy (Figure 2). The TNMB (tumor, node, metastasis, blood) classification for clinical staging is used according to the Mycosis Fungoides Cooperative Group staging system ${ }^{11}$ established in 1979 by Bunn and Lamberg, which was revised by the International Society for Cutaneous Lymphomas/European Organization for Research and Treatment of Cancer (EORTC)
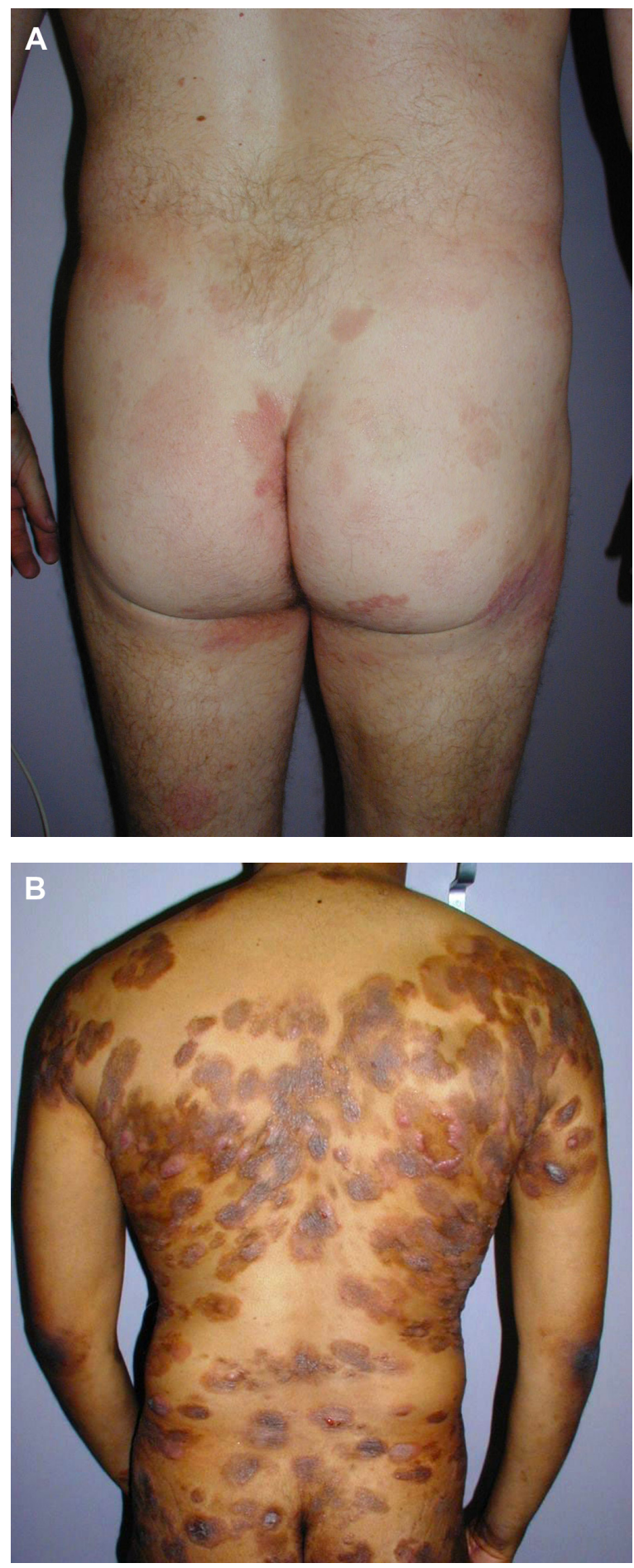

Figure I Patients with mycosis fungoides presenting with limited (A) patches/ plaques typically involving the buttocks, and with disseminated (B) patches/plaques and tumors.

staging proposal in 2007. ${ }^{12}$ Advanced clinical stages range from IIB (skin tumors) to IVB (visceral disease).

While the overall survival rate of patients with mycosis fungoides is $68 \%$ at 5 years and $17 \%$ at 30 years, the specific survival of patients ranges widely, depending on 


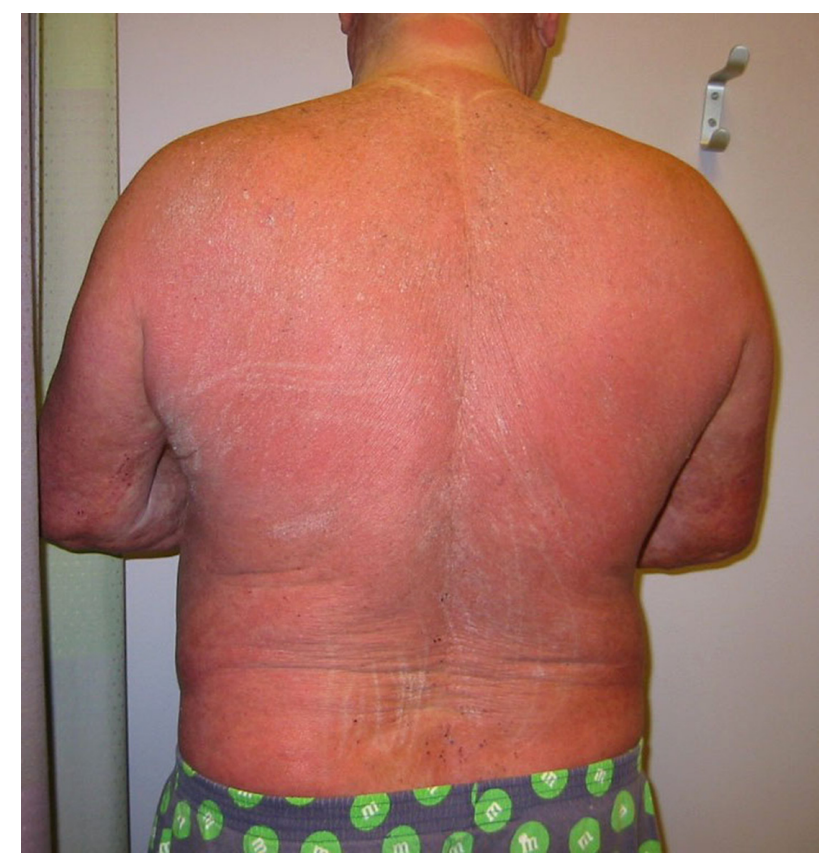

Figure 2 Patient with Sézary syndrome presenting clinically with generalized erythroderma and thickening (lichenification) of the skin.

T classification and stage at initial presentation. ${ }^{8}$ The largest study, consisting of 525 patients, showed an overall survival of $97 \%$ in patients with T1 (less than $10 \%$ body surface involvement) at 5 years, compared with $40 \%$ and $41 \%$ in $\mathrm{T} 3$ and T4 disease, respectively. ${ }^{8}$ Other studies have shown that elevated lactate dehydrogenase, large-cell transformation, and folliculotropic mycosis fungoides are associated with a worse prognosis. ${ }^{13,14}$ Patients with Sézary syndrome have an estimated 5-year survival of $24 \% .{ }^{4,8}$ Recent analyses of outcomes in patients with mycosis fungoides or Sézary syndrome using the International Society for Cutaneous Lymphoma/EORTC revised staging proposal established that the presence of a $\mathrm{T}$ cell clone in blood (identical to the cutaneous $\mathrm{T}$ cell clone) in the absence of morphologic evidence of blood involvement (B0b) was also associated with a significantly worse overall survival and disease-specific survival compared with those patients with no peripheral blood $\mathrm{T}$ cell clone (B0a). ${ }^{12,13}$

Research on new therapies for CTCL is largely centered on defining novel targets for therapy. The International Society for Cutaneous Lymphomas, the United States Cutaneous Lymphoma Consortium, and the Cutaneous Lymphoma Task Force of the EORTC have developed consensus guidelines to facilitate collaboration in clinical trials. ${ }^{15}$ These proposed guidelines consist of: recommendations for standardizing general protocol design; a scoring system for assessing tumor burden in skin, lymph nodes, blood, and viscera; definition of response in skin, nodes, blood, and viscera; a composite global response score; and a definition of end points. Although these guidelines were generated by consensus panels, they have not been prospectively or retrospectively validated by analysis of large patient cohorts. This review focuses on current and new discoveries that have provided targets for therapy in patients with mycosis fungoides or Sézary syndrome. We will briefly give an overview of recent molecular discoveries and dysregulated signaling pathways, followed by a presentation of current and novel topical, biological, and chemotherapy treatments for CTCL patients.

\section{Immunologic and molecular findings in mycosis fungoides and Sézary syndrome}

\section{Immunologic mechanisms of pathogenesis} Most malignant $\mathrm{T}$ cells in CTCL are clonally derived from CD4+ T helper memory cells. ${ }^{16}$ In the early stages of mycosis fungoides, the $\mathrm{T}$ cell infiltrate consists of both malignant CD4+ and reactive CD8+ T cells, with a dominance of Th1 cytokines, such as interferon-gamma (IFN)- $\gamma$, interleukin (IL)-12, and IL-2. ${ }^{17}$ In the later stages, there is a gradual increase in malignant CD4+ cells, a decrease in nonmalignant CD8+ cells, and a shift to Th2 cytokine dominance (IL-4, IL-5, IL-10, and IL-13). ${ }^{18}$ These changes correlate with disease progression, host immunosuppression, and susceptibility to infection. ${ }^{19}$ Biologic immune modifiers, such as IFN- $\alpha$, IFN- $\gamma$, and IL-12, are therapeutically effective in CTCL by stimulating Th1 cytokines and boosting host immune responses. The recently discovered Th17 lineage of CD4+ T cells functions in host protection against extracellular bacteria and fungi. ${ }^{20} \mathrm{Th} 17$-derived cytokines (IL-17, IL-21, and IL-22) have been implicated in autoimmunity. ${ }^{21}$ Recently, the Th1/Th2 paradigm of CTCL has been revisited, including a role for a IL-17-producing T cell (Th17) population in cutaneous lesions of patients with mycosis fungoides or Sézary syndrome..$^{22}$ Interestingly, IL-17 was not measurable in serum samples of patients with mycosis fungoides or Sézary syndrome, suggesting that this cytokine may only play a role in cutaneous lesions. In another study, IL-17 protein was found to be mediated by IL-2/IL-15 through the Jak3/STAT3 pathway. ${ }^{23}$ Other immune regulatory molecules found to be overexpressed in CTCL include IL-15, IL-16, and IL-21, and programmed death-1 (PD-1). ${ }^{24-27}$

Controversial results have been found for PD-1 expression. Increased PD-1 expression has been shown on circulating CD4+ cells in patients with Sézary syndrome 
when compared with patients with mycosis fungoides, which could imply a role for an increase in PD-1 expression in the progression of tumors. ${ }^{26}$ However, recent data showed increased PD-1 in pseudolymphoma and cutaneous $\mathrm{CD}^{+}{ }^{+}$small/medium-sized pleomorphic T cell lymphoma. ${ }^{28}$ Further research is needed in this area to determine whether the increase in PD-1 expression protects tumor cells from elimination, or if the increased PD-1 expression is a response of immunocompetent cells that are simply chronically stimulated by tumor antigens.

Chemokines and chemokine receptors in CTCL have been reviewed by others. ${ }^{29,30}$ They mediate not only trafficking of malignant $\mathrm{T}$ cells into the skin, but also their survival, possibly due to activation of prosurvival pathways. Chemokine receptor 4 (CCR4) is not only necessary for skin-homing of normal CD4+ T lymphocytes, but also for malignant CTCL cells. ${ }^{31,32}$ Both CCR4 and CCR10 have been shown to be highly expressed in CTCL skin lesions ${ }^{33}$ and in the peripheral blood cells of patients with mycosis fungoides or Sézary syndrome. ${ }^{34,35}$ While CCL17, a CCR4 ligand expressed on epidermal keratinocytes, endothelial cells, and dendritic cells, facilitates extravasation and migration of CTCL cells into the skin and epidermis, CCL27, a CCR10 ligand expressed on keratinocytes, has been implicated in both skin and nodal homing of CTCL cells. Anti-CCR4 is currently being evaluated in clinical trials including CTCL patients.

Naturally occurring regulatory $\mathrm{T}$ cells (Tregs, CD4+ CD25+ FOXP3+ phenotype) suppress the activity of other immune cells and thus maintain immunological tolerance. Tregs appear to be dysregulated in CTCL. ${ }^{36}$ Early cutaneous lesions in patients with mycosis fungoides contain numerous FOXP3+-infiltrating Tregs that decrease in number in advanced lesions. The high frequency of FOXP3+-infiltrating Tregs may suppress tumor proliferation and have been correlated with improved survival. ${ }^{36}$ Patients with Sézary syndrome have very low levels of Tregs but high levels of malignant $T$ cells expressing a Treg phenotype (FOXP3+ CD25-). These malignant FOXP3 + Tregs express CTLA-4, IL-10, and transforming growth factor- $\beta$, which suppress immunity and diminish the antitumor response. ${ }^{19}$

Cytotoxic T lymphocyte antigen (CTLA-4) is a coinhibitory molecule expressed on $\mathrm{T}$ cells that inhibits $\mathrm{T}$ cell activation and proliferation ${ }^{37}$ and confers resistance against activation-induced cell death. ${ }^{38}$ Tregs also constitutively express CTLA-4, which is necessary for their functioning to maintain peripheral tolerance and to prevent autoimmunity. ${ }^{39,40}$ High CTLA-4 expression was found in peripheral blood mononuclear cells from patients with mycosis fungoides, and higher expression levels correlated with increased tumor burden. Th1-derived cytokines, such as IL-2 and IFN- $\gamma$, upregulate expression of CTLA-4. ${ }^{41}$ Whether increased CTLA-4 expression relates to Treg-like properties that CTCL cells acquire during disease progression is not clear; further research is needed to prove this concept. Anti-CTLA-4 (ipilimumab) is an important immunotherapeutic strategy in melanoma; the association of dysregulated CTLA-4 in CTCL suggests a potential therapeutic target in this disease.

\section{Epigenetic mechanisms of pathogenesis}

DNA methylation of $\mathrm{CpG}$ islands in promoter regions is an epigenetic mechanism of gene expression that tightens chromatin around nucleosomes and interferes with binding of transcription factors. ${ }^{42}$ This has been shown to downregulate expression of tumor suppressor genes, leading to carcinogenesis in several tumor types. ${ }^{43}$ In CTCL, promoter hypermethylation leads to dysregulation of the cell cycle ( $p 15, p 16, p 73)$, apoptosis (TMS1,p73), DNA repair (MGMT), chromosomal instability (CHFR), and microsatellite instability (MLH1) genes and proteins. ${ }^{4-48}$ Promoter hypermethylation of $p 15$, p16, and $M L H 1$ was found in both early and advanced stages of mycosis fungoides and Sézary syndrome, suggesting that early epigenetic alterations were responsible for the inactivation of these genes. ${ }^{46-48}$

When genes are hypermethylated and silenced, the histones are in a deacetylated state. ${ }^{42}$ Acetylation of histones in nucleosomes alters conformation of chromatin. Histone deacetylases (HDACs) remove acetyl groups, leading to compaction of chromatin and repression of transcription. ${ }^{49}$ In addition to their action on histones, HDACs also regulate various transcription factors, such as the p53 tumor suppressor and E2F oncogene. ${ }^{49}$ HDACs were initially developed to restore tumor suppressor and cell regulatory genes by inducing histone hyperacetylation. ${ }^{50}$

\section{Apoptotic mechanisms of pathogenesis}

Defective regulation of apoptosis is a central feature of the pathology of several lymphoma types, including mycosis fungoides and Sézary syndrome. Apoptosis can be triggered by death receptors that belong to the tumor necrosis factor receptor family or by aberrations in expression of the $\mathrm{B}$ cell lymphoma-2 (Bcl-2) family. Malignant CD4+ T cells from cutaneous lesions and peripheral blood samples in mycosis fungoides and Sézary syndrome have decreased and/or defective Fas expression, and decreased Fas expression has been correlated with more aggressive disease as well as resistance 
to Fas-mediated apoptosis. ${ }^{51-54}$ Thus, downregulation of Fas may be one way in which CTCL cells become resistant to chemotherapy. Downregulation of Fas in CTCL occurs through multiple mechanisms, ie, mutations in the Fas gene, ${ }^{52}$ production of nonfunctioning splice variants, ${ }^{55}$ and promoter hypermethylation. ${ }^{56}$ In this context, malignant $\mathrm{T}$ cells in CTCL may acquire resistance to FasL signaling through increased expression of cFLIP, an intracellular apoptosis inhibitor. $^{51}$

The expression of other antiapoptotic molecules, such as p53 and Bcl-2 family members, has been studied in CTCL. In one in vitro study, p53 mutations were identified in tumor stage mycosis fungoides, but not in patch/plaque mycosis fungoides. ${ }^{57}$ In another study, there was no correlation between clinical stage and p53 mutations. ${ }^{58}$ One pathway being targeted for antineoplastic therapy is the antiapoptotic Bcl-2 and Bcl-2-like family of proteins. T cells generally express Bcl-2 that inhibits apoptosis and is widely and stably expressed in all stages of mycosis fungoides. ${ }^{59}$ Data suggested that inhibition of Stat3 signaling in CTCL cells through the Jak kinase inhibitor, Ag490, induced apoptosis through decreased expression of antiapoptotic Bcl-2 and increased expression of the proapoptotic Bax protein. ${ }^{60}$ Surprisingly, other investigators found late-stage disease and shorter survival time were correlated with decreased Bcl-2 expression. ${ }^{58}$ However, information about quantification of $\mathrm{Bcl}-2$ protein expression was not provided. It also remains unclear whether the low expression is related to alterations of genes, such as p53, that impact Bcl-2 expression.

Polo-like kinase 1 (Plk1) is a member of the PLK family of serine/threonine kinases crucial to the cell division cycle, which has been postulated to induce oncogenesis in multiple solid and hematologic malignancies. ${ }^{61-64}$ Increased expression has been found with progression and metastasis. Plk1 expression is elevated in CTCL, and in particular is found in tumor-stage and in folliculotropic and erythrodermic types of CTCL. ${ }^{65,66}$ In vitro studies with both small molecule inhibition and shRNA-mediated knockdown of Plk1 resulted in decreased cell growth, decreased cell viability, G2/M arrest, and apoptosis in CTCL cells. ${ }^{66}$ In addition, CTCL cell lines with $p 53^{35}$ and $k$-ras ${ }^{36}$ mutations appear to be sensitive to Plk inhibition and may serve as biomarkers for patient selection. Currently there are a number of Plk inhibitors in preclinical development, ${ }^{67}$ and results have been reported from Phase I studies for four of them (BI 2536, ${ }^{68} \mathrm{GSK}$ 461364, ${ }^{69} \mathrm{ON}-01910,{ }^{70}$ and HMN-21471). Although these inhibitors were studied mainly in solid tumors, with modest responses reported and prolongation of stable disease at best, they have yet to be studied in CTCL. Plk1 could serve as a potential target in advanced stages, when its expression is generally high.

The existence of multiple mechanisms of oncogenesis in CTCL and the variety of mechanistic combinations in individual patients may perhaps require more individualized therapy. A recent report of cotreatment with the HDAC inhibitor, panobinostat, and the Bcl-2 antagonist, ABT-737, found synergistic induction of apoptosis in CTCL cells. ${ }^{72}$

\section{Molecular mechanisms of pathogenesis}

Genome-wide analysis of chromosomal alterations is increasingly used as a research tool in the search for novel agents to treat CTCL. ${ }^{73-75}$ Improvements in microarray technology and computational analysis of genomic data have led to discoveries of underlying chromosomal mutations in tumor suppressor and oncogenes involved in CTCL. ${ }^{73-75}$ Chromosomal regions with significant gains include $8 \mathrm{q}$ (including the $M Y C$ oncogene), 17q, and 10p13 (including GATA3, a transcription factor which promotes Th2 cytokine production). ${ }^{74}$ Additionally, a recent study suggested that amplifications on $4 \mathrm{q} 12$ (including KIT), 7p11.2 (including EGFR), and $17 q 25.1$ may be highly associated with patients refractory to treatment. ${ }^{74}$ Specific oncogenes have been examined for defining new prognostic factors in CTCL. Deletions have been found on chromosomes 17p (including TP53), 10p, and $10 \mathrm{q}$ (including $P T E N$ and $F A S$ ), $13 \mathrm{q}$ including $R B 1$, and 9p21.3 (including $C D K N 2 A){ }^{74}$

MicroRNAs (miRNAs) are small noncoding RNAs that regulate gene expression. miRNAs have been shown to become dysregulated in cancer, providing the basis for development of miRNA-targeted cancer therapies. ${ }^{76}$ A microarray screen found that five miRNAs (miR-203, miR-205, miR-326, miR-663b, and miR-711) distinguish CTCL from benign skin diseases, with an accuracy of greater than $90 \%{ }^{77}$ In tumor-stage mycosis fungoides, miR-93, miR-92A, and miR-155 were upregulated in comparison with benign inflammatory skin diseases. ${ }^{78}$ In Sézary syndrome, most miRNAs were downregulated, but miR-21, miR-486, and miR-214 are upregulated and are involved in apoptotic resistance. ${ }^{79}$ miR-21 has been shown to mediate oncogenic signaling by STAT3 and may be a possible therapeutic target for Sézary syndrome. ${ }^{27,80}$

\section{Current and emerging therapies for early-stage disease}

Patients with early-stage mycosis fungoides often present with disease limited to the skin without systemic 
involvement; in these patients, a durable response can be achieved in approximately $60 \%-80 \%$ of cases with skindirected therapies. Patients with early-stage disease may be effectively treated with topical agents, because previous data have demonstrated that there is no benefit to aggressive use of systemic chemotherapy. ${ }^{81}$ Existing therapeutic approaches include phototherapy with psoralen plus ultraviolet A (PUVA), narrowband ultraviolet B (NB-UVB), total electron beam irradiation (TSEBT), and topical formulations of corticosteroids, nitrogen mustard, and retinoids/rexinoids. Success rates with PUVA are $90 \%$ for stage IA, $76 \%$ for stage IB, $78 \%$ for stage IIA, $59 \%$ for stage IIB $\%$, and $61 \%$ for stage III CTCL. ${ }^{82-84}$ The most common reported acute side effects were erythema, pruritus, and nausea. Long-term exposure was associated with an increased risk for developing chronic photodamage and nonmelanoma skin cancer. ${ }^{84}$

Recent consensus from the EORTC indicates that patients with patches and thin plaques should be given NB-UVB treatment, whereas PUVA should be reserved for patients with folliculotropic mycosis fungoides, failure of NB-UVB treatment, or dark complexion, due to carcinogenic effects, as well as a paucity of available treatment centers. ${ }^{85}$ Earlystage refractory patients may benefit from combination therapies, such as NB-UVB or PUVA with low-dose systemic oral bexarotene, acitretin, or IFN- $\alpha .{ }^{86}$ High-potency topical corticosteroids have also been shown to have an overall response rate of $>90 \%$ in patch-stage mycosis fungoides, with some side effects of irritant dermatitis and cutaneous atrophy. ${ }^{87,88}$ Topical nitrogen mustard has a complete response rate of $76 \%-80 \%$ for stage IA and 35\%-68\% complete response rate for stage IB disease. ${ }^{89}$ Common side effects are contact hypersensitivity reactions. Bexarotene gel is a retinoid $\mathrm{X}$ receptor agonist and is approved for early-stage mycosis fungoides. ${ }^{90}$ In clinical trials, it has been shown to have an overall response rate (ORR) of 54\% and a complete response rate of $10 \%$ in patients with stages IA-IIA mycosis fungoides. It commonly causes skin irritation. Tazarotene gel, a retinoic acid receptor agonist, is another topical retinoid approved for use in psoriasis and acne, and has been shown to improve skin lesions in refractory mycosis fungoides and may be useful as an adjuvant topical treatment. ${ }^{91}$ TSEBT is a procedure that involves administering ionizing radiation to the entire skin surface. ${ }^{83}$ TSEBT has been shown to be an effective therapy for palliation of the cutaneous symptoms of mycosis fungoides and Sézary syndrome. ${ }^{83}$ Because the electron beam radiation in TSEBT has greater energy and depth of penetration than other skin-directed therapies, it may be an option for treatment of stage T2 or T3 mycosis fungoides. ${ }^{83}$
Options may be limited for Caucasian patients, and TSEBT toxicity can be cosmetically disfiguring. A recent study from Stanford followed 180 patients with T2 or T3 mycosis fungoides on TSEBT treatment and found that all patients had over $50 \%$ improvement in skin involvement, with 63\% achieving a complete clinical response $(75 \%$ for $\mathrm{T} 2$ patients and $47 \%$ for T3 patients) with a median duration of response of 29 months in T2 patients and 9 months in T3 patients. ${ }^{83}$ These results confirm the work of previous studies showing that a conventional dose (30-36 Gy) of TSEBT is significantly more efficacious in T2 than in T3 mycosis fungoides.

Newer topical and investigational therapies include Toll-like receptor (TLR) agonists, gene therapy agents, $308 \mathrm{~nm}$ excimer laser, and photodynamic therapy. Imiquimod (Aldara $^{\circledR}$ cream 5\%), a TLR-7 agonist that induces tumor necrosis factor (TNF)- $\alpha$, IFN- $\alpha$, and IFN- $\gamma$ expression, has been shown to cause clinical and histologic clearance of limited skin lesions in a small number of patients. ${ }^{92-95}$ TG-1042 is a replication-deficient adenovirus vector expressing IFN- $\gamma$ that has been shown to induce a Th1 response when injected intralesionally. ${ }^{96}$ A recent Phase II trial of repeated intralesional TG-1042 injections had a local response rate of $46 \%$ in CTCL patients and minimal adverse effects, including injection site reactions, lymphopenia, fever, and chills. ${ }^{97}$ Further, $308 \mathrm{~nm}$ excimer laser has been shown to be an effective and well tolerated therapy for limited-stage mycosis fungoides in several small studies. It may be preferred over NB-UVB due to its greater precision in localizing treatment to small skin lesions, leading to decreased phototoxicity and better patient compliance. However, cost and availability are limitations. ${ }^{98-103}$ Photodynamic therapy utilizes a photosensitizer, light, and oxygen to induce reactive oxygen species. Two photosensitizers, 5-aminolevulinic acid (ALA; Levulan $^{\circledR}$ ) and methyl aminolevulinate hydrochloride have been used in CTCL. Treatment with ALA had efficacy in localized CTCL but not in tumor-stage CTCL, possibly due to insufficient penetration of 5-ALA and/or light. ${ }^{104,105}$ Common adverse effects of ALA include pain that occurs during light exposure, erythema, edema, and postinflammatory pigment changes. ${ }^{106}$ Due to the limited efficacy and side effect profile of ALA, other photosensitizers have been recently tested in CTCL. Methyl aminolevulinate hydrochloride, the methyl ester derivative of ALA, with greater lipophilia resulting in increased penetration and less pain, induced a complete response in six of seven cases of resistant unilesional patch-stage mycosis fungoides, with no recurrence during follow-up periods from 12 to 34 months. ${ }^{107-109}$ Silicon phthalocyanine Pc 4 has been shown to induce apoptosis in 
peripheral blood mononuclear cells from patients with Sézary syndrome. ${ }^{110}$ Hypericin ointment, another photosensitizer, induced a response in a Phase II trial of 12 patients, with adverse effects of burning, itching, erythema, and pruritus at the site of application. ${ }^{111}$

\section{Current and emerging therapies for advanced-stage disease Biological therapies}

Patients with advanced disease (stage IIB-IVB) may have disseminated disease into lymph nodes and other organs, and may exhibit multiple immune derangements necessitating systemic therapy. While no regimen has been proven to prolong survival in the advanced stages, immunomodulatory regimens should be used initially to reduce the need for cytotoxic therapies. Decreased cell-mediated immunity with a dominant Th2 cytokine profile is observed in advanced stages of mycosis fungoides and Sézary syndrome. Bexarotene, immunomodulatory cytokines such as IFN- $\alpha$, IFN- $\gamma$, and IL-12, and extracorporeal photopheresis enhance the host antitumor response by either maintaining Th1 skewing or inhibition of Th2 cytokine production.

Extracorporeal photopheresis, approved in 1988 by the US Food and Drug Administration (FDA) for the palliative treatment of patients with CTCL, is best suited to patients with Sézary syndrome, within 2 years of disease onset, near normal counts of CD8+ T cells and natural killer cells, and modest tumor burden. ${ }^{12}$ Overall response rates have ranged from $31 \%$ to $73 \%$ when CTCL patients are treated with extracorporeal photopheresis as monotherapy, but have been shown to have greater efficacy in various combinations with IFN- $\alpha$, IFN- $\gamma$, granulocyte-macrophage colony-stimulating factor, and bexarotene, due to enhancement of antitumor immunity. ${ }^{113,114}$ The novel continuous flow separation system (Therakos ${ }^{\mathrm{TM}}$ Cellex ${ }^{\mathrm{TM}}$ ) has been developed based on the current $\mathrm{Uvar}^{\circledR} \mathrm{XTS}^{\mathrm{TM}}$ photopheresis device and is designed to reduce treatment times and extracorporeal volumes.

IFN- $\alpha$ is one of the most widely used first-line treatments and probably the most effective single agent in the treatment of CTCL. It has shown a wide range of biologic effects, including antiviral, antiproliferative, and immunomodulatory actions. The exact mechanism by which interferons exert their antitumor effects remains unknown. Th1 cytokines support cytotoxic $\mathrm{T}$ cell-mediated immunity and it has been speculated that IFN- $\alpha$ maintains or enhances a Th1 cell population balance for an effective cell-mediated response to malignant $\mathrm{T}$ lymphocytes. A response rate of $73 \%$ in stage IA-IIA and
$60 \%$ response in stage IIB-IVA disease has been seen with IFN- $\alpha$ monotherapy. ${ }^{115}$ When IFN- $\alpha$ is used in combination with PUVA, both overall response rates and response duration show improvement, with studies demonstrating overall response and complete response rates of $98 \%$ and $84 \%{ }^{116,117}$ While the optimal dose and duration has not been established yet in CTCL, current experience suggests that therapy should be given at a starting dose of 1-3 million units five times weekly, with gradual escalation to 6-9 million units daily or as tolerated.

\section{Denileukin diftitox}

Denileukin diftitox $\left(\right.$ Ontak $\left.^{\circledR}\right)$ is an IL-2 diphtheria toxin fusion protein targeted against malignant $\mathrm{T}$ cells expressing CD25, the high-affinity IL-2 receptor. Denileukin diftitox was approved by the FDA in 1999 for the treatment of patients with CTCL refractory to standard treatment options. In general, response rates in patients with relapsed and refractory mycosis fungoides or Sézary syndrome range from $30 \%$ to $37 \%$. ${ }^{118}$ A recent randomized Phase III trial in CD25 + CTCL demonstrated an ORR of 44\% for patients treated with denileukin diftitox versus $15.9 \%$ for patients on placebo. CTCL patients were randomly assigned to denileukin diftitox $9 \mu \mathrm{g} / \mathrm{kg} /$ day $(\mathrm{n}=45)$, denileukin diftitox $18 \mu \mathrm{g} / \mathrm{kg} /$ day $(\mathrm{n}=55)$, or placebo infusions $(\mathrm{n}=44)$. In addition, patients treated with both doses of denileukin diftitox had a significantly longer progression-free survival than patients on placebo. ${ }^{119}$ The incidence of grade 3 and 4 capillary leak syndrome was seen in $2-3$ patients $(3.6 \%)$ at doses of $18 \mu \mathrm{g} / \mathrm{kg} /$ day. A key remaining question of whether response to denileukin diftitox depends on expression of CD25 was explored in a retrospective study of complete responders in previous Phase II and Phase III trials. This study found no difference in response between patients with CD25-positive and CD25-negative disease. ${ }^{120}$

\section{Histone deacetylase inhibitors}

HDAC inhibitors were initially developed to modulate chromatin condensation by acetylation of histones affecting gene expression. More recently, their effects on posttranslational modification of many intracellular proteins have been recognized. ${ }^{121}$ Vorinostat (suberoylanilide hydroxamic acid; Zolinza ${ }^{\circledR}$ ), an orally administered HADC inhibitor, was approved by the FDA in 2006 for the treatment of relapsed/refractory CTCL. A Phase IIB trial was conducted in 74 patients with stage IB-IVA CTCL, including $82 \%$ with $\geq$ stage IIB disease. ORR was $29.7 \%$. Oral vorinostat was administered at $400 \mathrm{mg}$ daily. The median time to 
response was 2 months and median duration of response was not reached, but was estimated to be longer than 6.1 months. In addition, $43.4 \%$ of patients with severe pruritus experienced relief. The most common adverse effects included diarrhea, fatigue, and nausea, but most were of grade 2 or lower. Significant grade 3 side effects included pulmonary embolism (5\%) and thrombocytopenia (5\%). In this study, QTc interval prolongation was observed in three patients with no reported clinical sequelae, none of which were grade 3 . There were no cases of infection. ${ }^{122}$ Another Phase II trial of vorinostat conducted in 33 patients with advanced or refractory CTCL at multiple doses demonstrated an ORR of $24 \%$ with a median time to response of 3 months and a median duration of response of 3.7 months. Forty-five percent of patients experienced relief of pruritus. ${ }^{123}$ In addition, analysis of lesion biopsies in responding patients demonstrated a shift in localization of phosphorylated STAT-3 from nuclear to cytoplasmic, suggesting that vorinostat may inhibit proliferation of CTCL cells by inactivating STAT3. ${ }^{124}$ Further in vitro work has shown that CTCL patients with high nuclear levels of STAT1 and pSTAT3 are resistant to vorinostat. ${ }^{124}$ Combination therapy has also been investigated, and PI3 K inhibitors have been found to synergize with vorinostat in reducing cell viability. ${ }^{125}$

Romidepsin (depsipeptide, Istodax ${ }^{\circledR}$ ) is another HDAC inhibitor recently approved by the FDA for patients with relapsed/refractory CTCL. Two Phase II trials were conducted in a total of 167 patients suffering from relapsed, refractory, or advanced CTCL. ${ }^{126,127}$ Romidepsin was administered intravenously at $14 \mathrm{mg} / \mathrm{m}^{2}$ on days 1,8 , and 15 of a 28 -day cycle. In both trials, the ORR was $34 \%$, the complete response rate was $6 \%$, the median time to response was 2 months, and median duration of response was longer than 12 months. The most common adverse effects were fatigue, nausea, vomiting, and anorexia. Severe adverse effects included leukopenia, lymphopenia, granulocytopenia, thrombocytopenia, and anemia. Earlier studies have shown that HDAC inhibitors may be associated with electrocardiographic abnormalities, such as QTc interval prolongation. ${ }^{128}$ In one trial, 9\% of patients had QTc prolongation and $80 \%$ had asymptomatic $\mathrm{T}$ wave flattening or ST segment depression. ${ }^{126}$ The other trial had no patients with QTcF values $>480$ milliseconds or an increase of $>60$ milliseconds over baseline. It was also found that antiemetics might contribute to QTcF prolongation. ${ }^{127}$

Panobinostat (LBH589) is another HDAC inhibitor that was shown in a Phase I trial to induce clinical responses in CTCL patients. ${ }^{129}$ Preliminary results of a Phase II trial of oral panobinostat have been reported. Panobinostat was administered at a dose of $20 \mathrm{mg}$ on days 1, 3, and 5 weekly in bexarotene-treated patients and bexarotene-naïve patients. In 62 bexarotene-treated patients, $17.7 \%$ achieved a response. In 35 bexarotene-naïve patients, 12.1\% achieved a response. Thrombocytopenia, neutropenia, pruritus, diarrhea, and hypophosphatemia were the most common grade 3 or 4 toxicities. Two patients had QTcF > 480 milliseconds and four had an increase in $\mathrm{QTcF}>60$ milliseconds from baseline. ${ }^{130}$

Another HDAC inhibitor, belinostat (PDX101), is currently being evaluated in a Phase II trial of patients with relapsed/refractory peripheral $\mathrm{T}$ cell lymphoma that includes anaplastic large cell lymphoma and subcutaneous panniculitis-like $\mathrm{T}$ cell lymphoma. The treatment schedule is $1000 \mathrm{mg} / \mathrm{m}^{2}$ intravenously on days $1-5$ of a 21-day cycle. Of 19 evaluable patients so far, the ORR was $32 \%$ with a median time to response of 8 months.

\section{Monoclonal antibodies}

Monoclonal antibodies target tumor cells via cell surface markers upregulated on malignant $\mathrm{T}$ cells such as CD4, CD52, and CCR4. Zanolimumab (Hu-Max CD4) is a humanized anti-CD4 monoclonal antibody that has been shown in vitro to mediate antibody-dependent cellular cytotoxicity, primarily in CD4 + CD45RO + T cells. ${ }^{131}$ Zanolimumab also blocks $\mathrm{T}$ cell activation by macrophages in Pautrier's micro abscesses via induction of inhibitory signaling pathways involving SHIP-1 and DOK-1. ${ }^{132}$ In two Phase II studies done in 47 patients with refractory early-stage and advancedstage CTCL, zanolimumab was given intravenously at a weekly dose of $280 \mathrm{mg}$ and $560 \mathrm{mg}$ for early-stage patients and $280 \mathrm{mg}$ and $980 \mathrm{mg}$ for late-stage patients. The ORR was $56 \%$ in patients with mycosis fungoides treated with a high dose and $15 \%$ at a lower dose. In patients with Sézary syndrome, the ORR was $20 \%$ in patients treated with a high dose and $25 \%$ at a lower dose. Adverse events included skin inflammation (24\%) and infections of the skin and upper respiratory tract $(49 \%) .{ }^{133}$

Alemtuzumab (Campath ${ }^{\circledR}$ ), a humanized monoclonal antibody against CD52 surface antigen expressed on most malignant $\mathrm{T}$ cells, has been shown to mediate antibodydependent cellular cytotoxicity, ${ }^{134,135}$ complement-mediated cell lysis, ${ }^{136}$ and apoptosis. ${ }^{137}$ A Phase II study was conducted in 22 patients with advanced CTCL at a dose of $30 \mathrm{mg}$ intravenously three times a week. The ORR was 55\% (32\% complete response, $23 \%$ partial response). A greater effect was observed in patients with erythrodermic CTCL (69\% ORR) than on plaque or tumor CTCL (40\%). ${ }^{138}$ To investigate 
this preferential effect on erythrodermic CTCL, another Phase II study was conducted in 19 patients with advanced refractory erythrodermic CTCL and found an ORR of 84\%. ${ }^{139}$ Serious adverse events in these studies included infections and hematologic toxicity. Infections, occurring primarily in patients who had received three or more treatments, included cytomegalovirus reactivation, fever of unknown origin, herpes simplex virus reactivation, pulmonary aspergillosis, and Mycobacterium pneumonia. Hematologic toxicities included anemia, neutropenia, and thrombocytopenia. One study found adverse effects of congestive heart failure and arrhythmias following alemtuzumab treatment. ${ }^{140}$ However, several studies since have found no correlation with cardiac toxicity. ${ }^{139,141}$

\section{Chemotherapy}

Conventional systemic treatments include chemotherapeutic agents and biologic immunomodulatory therapies. Gemcitabine $\left(\right.$ Gemzar $\left.^{\circledR}\right)$ and pegylated doxorubicin $\left(\right.$ Doxil $\left.^{\circledR}\right)$ are being used as newer initial single-agent chemotherapeutic choices. ${ }^{142,143}$ A Phase II trial of gemcitabine reported a $68 \%$ ORR in 25 patients with refractory advanced CTCL. ${ }^{144}$ In advanced untreated CTCL, gemcitabine was shown to result in a $75 \%$ response rate in 32 patients. ${ }^{142}$ Another study showed a response rate of $88 \%$ for pegylated liposomal doxorubicin. ${ }^{143}$

\section{Pralatrexate: targeted antifolate therapy}

Methotrexate is the traditional antifolate used in therapy for lymphomas. It inhibits dihydrofolate reductase that converts dihydrofolate to tetrahydrofolate, which is required for synthesis of thymidylate and purine nucleotides involved in DNA and RNA synthesis. Pralatrexate $\left(\right.$ Folotyn $\left.^{\circledR}\right)$ belongs to a class of novel folate analogs, ie, the 10-deazaaminopterins, designed with greater affinity than methotrexate for receptorreduced folate carrier, leading to improved drug internalization through membrane transport. It is also a better substrate for polyglutamylation than methotrexate, leading to greater intracellular retention ${ }^{145,146}$ and 10-fold greater cytotoxicity than methotrexate in lymphoma cell lines. ${ }^{147}$ Pralatrexate has been approved by the FDA for relapsed or refractory peripheral $\mathrm{T}$ cell lymphoma.

Preliminary results of a multicenter dose-escalation Phase II study in 54 patients with relapsed or refractory CTCL have been reported. The starting dose and schedule was $30 \mathrm{mg} / \mathrm{m}^{2}$ intravenously once per week for 3 of 4 weeks. An optimal dose of $15 \mathrm{mg} / \mathrm{m}^{2}$ for 3 of 4 weeks was defined, at which the ORR was $43 \%$. The ORR was $50 \%$ at doses greater than $15 \mathrm{mg} / \mathrm{m}^{2}$. Most common grade 1-2 adverse effects included fatigue, mucositis, nausea, edema, epistaxis, pyrexia, constipation, and vomiting. Grade 3 adverse effects included thrombocytopenia, neutropenia, leukopenia, and anemia. ${ }^{148}$ In another report of 12 patients with mycosis fungoides and large-cell transformation who were part of the multicenter PROPEL (Pralatrexate in Patients With Relapsed or Refractory Peripheral T-Cell Lymphoma) trial for patients with peripheral T cell lymphoma, the ORR was $58 \%$ via investigator assessment and $25 \%$ via independent central review. ${ }^{149,150}$ Combination therapy with bortezomib is currently under exploration. ${ }^{151}$

\section{Hematopoietic stem cell transplantation}

The concept of high-dose combined chemotherapy followed by autologous bone marrow transplant or peripheral blood stem cell support has curative potential in various nonHodgkin lymphomas, but experience in CTCL is limited. Autologous stem cell transplants have yielded disappointing results. Despite reported effective responses with complete response in most patients treated, relapses are frequent and may occur rapidly. ${ }^{152,153}$ Allogeneic hematopoietic stem cell transplantation (HSCT) with myeloablative conditioning regimens provides a graft-versus-tumor effect and avoids reinfusion of tumor cells, both of which are features lacking in autologous HSCT. However, myeloablation places the patient at high risk for infections and graft-versus-host disease, rendering HSCT difficult to use in the elderly and in those with multiple comorbidities. With the broadened use of nonmyeloablative reduced-intensity conditioning regimens, allogeneic HSCT may now be better suited for patients with CTCL. ${ }^{154}$ A retrospective study of 60 patients with advanced CTCL who received allogeneic HSCT and either reducedintensity conditioning or myeloablative conditioning had a complete response rate of $60.5 \%$ and an overall survival of $54 \%$ at 3 years. Overall survival at 3 years in patients who received reduced-intensity conditioning was $63 \%$ compared with $29 \%$ in patients who received myeloablative conditioning. The median age of the patients was 46.5 years, indicating that allogeneic HSCT may be an effective treatment in younger as well as older patients. ${ }^{155}$ In another study of allogeneic HSCT with reduced-intensity conditioning and pretreatment TSEBT for tumor debulking, 58\% had a complete response, and overall survival at 2 years was $79 \%$. Causes of mortality included sepsis, metastatic nonsmall cell lung cancer, and disease progression. ${ }^{156}$ Cord blood transplantation has also been attempted with some success in Japan in cases of failure or inability to attempt allogeneic HSCT. ${ }^{157,158}$ 


\section{Investigational therapies Lenalidomide}

Lenalidomide $\left(\right.$ Revlimid $\left.^{\circledR}\right)$, an analog of thalidomide, is currently approved by the FDA for treatment of myelodysplastic syndrome ${ }^{159}$ and refractory/relapsed multiple myeloma. ${ }^{160}$ Its immunomodulatory properties, such as natural killer and $\mathrm{T}$ cell activation with induction of Th1 cytokine production and cytotoxic activity, along with alteration of the tumor cell microenvironment through antiangiogenic, antiproliferative, and proapoptotic properties, provided the rationale to use this agent in patients with CTCL. ${ }^{161} \mathrm{~A}$ Phase II trial in 35 patients with advanced/refractory CTCL showed an ORR of $32 \%$, a median time to response of 3 months, and a median duration of response of 4 months. ${ }^{162}$ The most common side effects were fatigue, lower leg edema, gastrointestinal symptoms, leukopenia, and neutropenia. Temporary tumor flares, characterized by an increase in size/number of skin lesions, tender swelling of lymph nodes, or increase in Sézary cell count, were noted in $25 \%$ of patients following initial treatment. Data from this study also suggest that the immunomodulatory effects of lenalidomide might be associated with decreased Treg and CD4+ $\mathrm{T}$ cell numbers.

\section{Oligonucleotides (nuclear acid therapeutics)}

TLR agonists represent a novel approach to stimulate an effective antitumor immune response in patients with CTCL through augmentation of either dendritic cells or $\mathrm{T}$ cell effects. PF-3512676 (CPG-7909, ProMune ${ }^{\circledR}$ ) is a TLR-9activating oligodeoxynucleotide and potent plasmacytoid dendritic cell stimulator ${ }^{163}$ that was recently shown in a dose-escalating Phase I trial to induce an ORR in $32 \%$ of patients (three complete responses, six partial responses) with treatment-refractory stage IB to IVA CTCL. ${ }^{164}$ Twenty-eight patients received subcutaneous doses $(0.08,0.16,0.24,0.28$, 0.32 , or $0.36 \mathrm{mg} / \mathrm{kg}$ ) once weekly for 24 weeks.

\section{Proteasome inhibitors}

Nuclear factor-kappa B (NF-kB) is an oncogenic transcription factor normally sequestered in an inactive state by the inhibitory I-kB molecule. Various oncogenic signals activate NF-kB via phosphorylation of I-kB, leading to its degradation via the $26 \mathrm{~S}$ proteasome. Downstream targets of NF-kB include cIAP1, cIAP2, and Bcl-2. ${ }^{165}$ Bortezomib inhibits the $26 \mathrm{~S}$ proteasome and therefore prevents degradation of I-kB and activation of NF-kB. ${ }^{166}$ It has been shown to induce apoptosis in CTCL via suppression of NF-kB-dependent antiapoptotic genes, cIAP1 and cIAP2, but not Bcl-2. ${ }^{165,167} \mathrm{~A}$ Phase II trial was conducted in 15 patients with relapsed/refractory cutaneous T cell lymphoma using a dose of $1.3 \mathrm{mg} / \mathrm{m}^{2}$ on days $1,4,8$, and 11 every 21 days, for a total of six cycles. The ORR was $67 \%$ (17\% complete responses, $50 \%$ partial responses). Common adverse effects were neutropenia, thrombocytopenia, and sensory neuropathy. ${ }^{168}$ Currently, a Phase I trial is being conducted in patients with refractory $\mathrm{T}$ cell lymphoma using a combination of bortezomib and 5-azacytidine, a DNA methyltransferase inhibitor.

\section{CCR4 antibody}

KW-0761, a novel defucosylated humanized monoclonal antibody against CCR4, enhances antibody-dependent cellular cytotoxicity against malignant CTCL cells. ${ }^{169}$ In vitro studies of KW-0761 using mycosis fungoides and Sézary syndrome cell lines, primary mycosis fungoides and Sézary syndrome cells, and mycosis fungoides and Sézary syndrome mouse models showed not only significant antibody-dependent cellular cytotoxicity-mediated antitumor activity, but also a synergistic effect with IL-12, IFN- $\alpha-2 b$, and IFN- $\gamma$. Phase I studies in adult $\mathrm{T}$ cell leukemia/lymphoma and peripheral $\mathrm{T}$ cell lymphoma have demonstrated an ORR of $31 \%$, with minimal adverse effects, consisting mainly of hematologic toxicities. ${ }^{170}$ Phase II studies are currently ongoing in patients with peripheral $\mathrm{T}$ cell lymphoma, CTCL, and adult $\mathrm{T}$ cell leukemia/lymphoma.

\section{Conclusion}

The significant strides that have been made in elucidating the mechanisms of pathogenesis in CTCL have allowed for the development of an extensive repertoire of targeted therapies. Patients with early-stage disease generally have an excellent prognosis and should be treated with skin-directed therapies. While no regimen has been proven to prolong survival in the advanced stages, immunomodulatory regimens are recommended initially to reduce the need for cytotoxic therapies. The existence of multiple mechanisms of oncogenesis in CTCL allows for a variety of mechanistic combinations and more individualized therapy. In more advanced stages of CTCL, treatment efforts should be made for palliation and improvement of quality of life. Unfortunately, other than allogeneic hematopoietic stem cell transplantation, there are no curative therapies for CTCL.

\section{Disclosures}

PM has received research support from Allos Therapeutics, Ligand Pharmaceuticals (now Eisai), Schering-Plough Corporation US Bioscience (now MedImmune), Bristol 
Myers Squibb, Merck, Orthobiotech, and Genmab. $\mathrm{SH}$ has served as an investigator and consultant, and received research support from Allos Therapeutics, Celgene, Seattle Genetics, Kiowa-Kirin, and is a consultant for Merck.

\section{References}

1. Girardi M, Heald PW, Wilson LD. The pathogenesis of mycosis fungoides. N Engl J Med. 2004;350(19):1978-1988.

2. Willemze R, Jaffe ES, Burg G, et al. WHO-EORTC classification for cutaneous lymphomas. Blood. 2005;105(10):3768-3785.

3. Bradford PT, Devesa SS, Anderson WF, Toro JR. Cutaneous lymphoma incidence patterns in the United States: a population-based study of 3884 cases. Blood. 2009;113(21):5064-5073.

4. Burg G, Kempf W, Cozzio A, et al. WHO/EORTC classification of cutaneous lymphomas 2005: histological and molecular aspects. J Cutan Pathol. 2005;32(10):647-674.

5. Criscione VD, Weinstock MA. Incidence of cutaneous T-cell lymphoma in the United States, 1973-2002. Arch Dermatol. 2007;143(7): 854-859.

6. Campo E, Swerdlow SH, Harris NL, Pileri S, Stein H, Jaffe ES. The 2008 WHO classification of lymphoid neoplasms and beyond: evolving concepts and practical applications. Blood. 2011;117(19):5019-5032.

7. van Doorn R, Van Haselen CW, van Voorst Vader PC, et al. Mycosis fungoides: disease evolution and prognosis of 309 Dutch patients. Arch Dermatol. 2000;136(4):504-510.

8. Kim YH, Liu HL, Mraz-Gernhard S, Varghese A, Hoppe RT. Long-term outcome of 525 patients with mycosis fungoides and Sezary syndrome clinical prognostic factors and risk for disease progression. Arch Dermatol. 2003;139(7):857-866.

9. Wain EM, Orchard GE, Whittaker SJ, Spittle MF, Russell-Jones R. Outcome in 34 patients with juvenile-onset mycosis fungoides: a clinical, immunophenotypic, and molecular study. Cancer. 2003;98(10):2282-2290.

10. Crowley JJ, Nikko A, Varghese A, Hoppe RT, Kim YH. Mycosis fungoides in young patients: clinical characteristics and outcome. J Am Acad Dermatol. 1998;38(5 Pt 1):696-701.

11. Bunn PA Jr, Lamberg SI. Report of the committee on staging and classification of cutaneous T-cell lymphomas. Cancer Treat Rep. 1979;63(4):725-728

12. Olsen E, Vonderheid E, Pimpinelli N, et al. Revisions to the staging and classification of mycosis fungoides and Sezary syndrome: a proposal of the International Society for Cutaneous Lymphomas (ISCL) and the cutaneous lymphoma task force of the European Organization of Research and Treatment of Cancer (EORTC). Blood. 2007;110(6):1713-1722.

13. Agar NS, Wedgeworth E, Crichton S, et al. Survival outcomes and prognostic factors in mycosis fungoides/Sezary syndrome: validation of the revised International Society for Cutaneous Lymphomas/European Organisation for Research and Treatment of Cancer staging proposal. J Clin Oncol. 2010;28(31):4730-4739.

14. Gerami P, Rosen S, Kuzel T, Boone SL, Guitart J. Folliculotropic mycosis fungoides: an aggressive variant of cutaneous T-cell lymphoma. Arch Dermatol. 2008;144(6):738-746.

15. Olsen EA, Whittaker S, Kim YH, et al. Clinical end points and response criteria in mycosis fungoides and Sezary syndrome: a consensus statement of the International Society for Cutaneous Lymphomas, the United States Cutaneous Lymphoma Consortium, and the Cutaneous Lymphoma Task Force of the European Organisation for Research and Treatment of Cancer. J Clin Oncol. 2011;29(18):2598-2607.

16. Berger CL, Warburton D, Raafat J, LoGerfo P, Edelson RL. Cutaneous T-cell lymphoma: neoplasm of $\mathrm{T}$ cells with helper activity. Blood. 1979;53(4):642-651

17. Saed G, Fivenson DP, Naidu Y, Nickoloff BJ. Mycosis fungoides exhibits a Th1-type cell-mediated cytokine profile whereas Sezary syndrome expresses a Th2-type profile. J Invest Dermatol. 1994;103(1):29-33.
18. Chong BF, Wilson AJ, Gibson HM, et al. Immune function abnormalities in peripheral blood mononuclear cell cytokine expression differentiates stages of cutaneous T-cell lymphoma/mycosis fungoides. Clin Cancer Res. 2008;14(3):646-653.

19. Krejsgaard T, Odum N, Geisler C, Wasik MA, Woetmann A. Regulatory $\mathrm{T}$ cells and immunodeficiency in mycosis fungoides and Sezary syndrome. Leukemia. 2011. [Epub ahead of print.]

20. Weaver CT, Hatton RD, Mangan PR, Harrington LE. IL-17 family cytokines and the expanding diversity of effector T cell lineages. Annu Rev Immunol. 2007;25:821-852.

21. Lowes MA, Bowcock AM, Krueger JG. Pathogenesis and therapy of psoriasis. Nature. 2007;445(7130):866-873.

22. Ciree A, Michel L, Camilleri-Broet S, et al. Expression and activity of IL-17 in cutaneous T-cell lymphomas (mycosis fungoides and Sezary syndrome). Int J Cancer. 2004;112(1):113-120.

23. Krejsgaard T, Ralfkiaer U, Clasen-Linde E, et al. Malignant cutaneous T-cell lymphoma cells express IL-17 utilizing the Jak3/Stat3 signaling pathway. J Invest Dermatol. 2011;131(6):1331-1338.

24. Asadullah K, Haeussler-Quade A, Gellrich S, et al. IL-15 and IL-16 overexpression in cutaneous T-cell lymphomas: stagedependent increase in mycosis fungoides progression. Exp Dermatol. 2000;9(4):248-251

25. Richmond J, Tuzova M, Parks A, et al. Interleukin-16 as a marker of Sezary syndrome onset and stage. J Clin Immunol. 2011;31(1):39-50.

26. Samimi S, Benoit B, Evans K, et al. Increased programmed death-1 expression on $\mathrm{CD} 4+\mathrm{T}$ cells in cutaneous T-cell lymphoma: implications for immune suppression. Arch Dermatol. 2010;146(12):1382-1388.

27. van der Fits L, van Kester MS, Qin Y, et al. MicroRNA-21 expression in CD4+ T cells is regulated by STAT3 and is pathologically involved in Sezary syndrome. J Invest Dermatol. 2011;131(3):762-768.

28. Cetinozman F, Jansen PM, Willemze R. Expression of programmed death-1 in primary cutaneous CD4-positive small/medium-sized pleomorphic T-cell lymphoma, cutaneous pseudo-T-cell lymphoma, and other types of cutaneous T-cell lymphoma. Am J Surg Pathol. 2012;36(1):109-116.

29. Lonsdorf AS, Hwang ST, Enk AH. Chemokine receptors in T-cell-mediated diseases of the skin. J Invest Dermatol. 2009; 129(11):2552-2566.

30. Wu XS, Lonsdorf AS, Hwang ST. Cutaneous T-cell lymphoma: roles for chemokines and chemokine receptors. J Invest Dermatol. 2009;129(5):1115-1119.

31. Ferenczi K, Fuhlbrigge RC, Pinkus J, Pinkus GS, Kupper TS. Increased CCR4 expression in cutaneous $\mathrm{T}$ cell lymphoma. $J$ Invest Dermatol. 2002;119(6):1405-1410.

32. Campbell JJ, O'Connell DJ, Wurbel MA. Cutting edge: Chemokine receptor CCR4 is necessary for antigen-driven cutaneous accumulation of CD4 T cells under physiological conditions. J Immunol. 2007;178(6):3358-3362.

33. Notohamiprodjo M, Segerer S, Huss R, et al. CCR10 is expressed in cutaneous T-cell lymphoma. Int J Cancer. 2005;115(4):641-647.

34. Sokolowska-Wojdylo M, Wenzel J, Gaffal E, et al. Circulating clonal CLA(+) and CD4(+) T cells in Sezary syndrome express the skin-homing chemokine receptors CCR4 and CCR10 as well as the lymph node-homing chemokine receptor CCR7. Br J Dermatol. 2005;152(2):258-264.

35. Ando K, Ozaki T, Yamamoto H. Polo-like kinase 1 (Plk1) inhibits p53 function by physical interaction and phosphorylation. $J$ Biol Chem. 2004;279(24):25549-25561.

36. Luo J, Emanuele MJ, Li D, et al. A genome-wide RNAi screen identifies multiple synthetic lethal interactions with the Ras oncogene. Cell. 2009;137(5):835-848.

37. Walunas TL, Lenschow DJ, Bakker CY, et al. CTLA-4 can function as a negative regulator of T cell activation. Immunity. 1994;1(5):405-413.

38. Schneider H, Valk E, Leung R, Rudd CE. CTLA-4 activation of phosphatidylinositol 3-kinase (PI 3-K) and protein kinase B (PKB/AKT) sustains T-cell anergy without cell death. PLoS One. 2008;3(12):e3842. 
39. Takahashi T, Tagami T, Yamazaki S, et al. Immunologic self-tolerance maintained by $\mathrm{CD} 25(+) \mathrm{CD} 4(+)$ regulatory $\mathrm{T}$ cells constitutively expressing cytotoxic T lymphocyte-associated antigen 4. J Exp Med. 2000;192(2):303-310.

40. Wing K, Onishi Y, Prieto-Martin P, et al. CTLA-4 control over Foxp3+ regulatory T cell function. Science. 2008;322(5899):271-275.

41. Wong HK, Wilson AJ, Gibson HM, et al. Increased expression of CTLA-4 in malignant T-cells from patients with mycosis fungoides - cutaneous T cell lymphoma. J Invest Dermatol. 2006;126(1): 212-219.

42. Herman JG, Baylin SB. Gene silencing in cancer in association with promoter hypermethylation. N Engl J Med. 2003;349(21):2042-2054.

43. Jones PA, Baylin SB. The fundamental role of epigenetic events in cancer. Nat Rev Genet. 2002;3(6):415-428.

44. van Doorn R, Zoutman WH, Dijkman R, et al. Epigenetic profiling of cutaneous T-cell lymphoma: promoter hypermethylation of multiple tumor suppressor genes including BCL7a, PTPRG, and p73. J Clin Oncol. 2005;23(17):3886-3896.

45. Navas IC, Ortiz-Romero PL, Villuendas R, et al. p16(Inatural killer 4a) gene alterations are frequent in lesions of mycosis fungoides. $A m J$ Pathol. 2000;156(5):1565-1572.

46. Scarisbrick JJ, Woolford AJ, Calonje E, et al. Frequent abnormalities of the p15 and p16 genes in mycosis fungoides and Sezary syndrome. J Invest Dermatol. 2002;118(3):493-499.

47. Gallardo F, Esteller M, Pujol RM, Costa C, Estrach T, Servitje O. Methylation status of the p15, p16 and MGMT promoter genes in primary cutaneous T-cell lymphomas. Haematologica. 2004;89(11):1401-1403.

48. Scarisbrick JJ, Mitchell TJ, Calonje E, Orchard G, Russell-Jones R, Whittaker SJ. Microsatellite instability is associated with hypermethylation of the hMLH1 gene and reduced gene expression in mycosis fungoides. J Invest Dermatol. 2003;121(4):894-901.

49. Marks P, Rifkind RA, Richon VM, Breslow R, Miller T, Kelly WK. Histone deacetylases and cancer: causes and therapies. Nat Rev Cancer. 2001;1(3):194-202.

50. Zhang C, Richon V, Ni X, Talpur R, Duvic M. Selective induction of apoptosis by histone deacetylase inhibitor SAHA in cutaneous T-cell lymphoma cells: relevance to mechanism of therapeutic action. J Invest Dermatol. 2005;125(5):1045-1052.

51. Contassot E, Kerl K, Roques S, et al. Resistance to FasL and tumor necrosis factor-related apoptosis-inducing ligand-mediated apoptosis in Sezary syndrome T-cells associated with impaired death receptor and FLICE-inhibitory protein expression. Blood. 2008;111(9):4780-4787.

52. Dereure O, Levi E, Vonderheid EC, Kadin ME. Infrequent Fas mutations but no Bax or p53 mutations in early mycosis fungoides: a possible mechanism for the accumulation of malignant $\mathrm{T}$ lymphocytes in the skin. J Invest Dermatol. 2002;118(6):949-956.

53. Dereure O, Portales P, Clot J, Guilhou JJ. Decreased expression of Fas (APO-1/CD95) on peripheral blood CD4+ T lymphocytes in cutaneous T-cell lymphomas. Br J Dermatol. 2000;143(6):1205-1210.

54. Zoi-Toli O, Vermeer MH, De Vries E, Van Beek P, Meijer CJ, Willemze R. Expression of Fas and Fas-ligand in primary cutaneous T-cell lymphoma (CTCL): association between lack of Fas expression and aggressive types of CTCL. Br J Dermatol. 2000;143(2):313-319.

55. van Doorn R, Dijkman R, Vermeer MH, Starink TM, Willemze R, Tensen CP. A novel splice variant of the Fas gene in patients with cutaneous T-cell lymphoma. Cancer Res. 2002;62(19):5389-5392.

56. Jones CL, Wain EM, Chu CC, et al. Downregulation of Fas gene expression in Sezary syndrome is associated with promoter hypermethylation. J Invest Dermatol. 2010;130(4):1116-1125.

57. McGregor JM, Crook T, Fraser-Andrews EA, et al. Spectrum of p53 gene mutations suggests a possible role for ultraviolet radiation in the pathogenesis of advanced cutaneous lymphomas. J Invest Dermatol. 1999;112(3):317-321

58. Kandolf Sekulovic L, Cikota B, Jovic M, et al. The role of apoptosis and cell-proliferation regulating genes in mycosis fungoides. J Dermatol Sci. 2009;55(1):53-56.
59. Dummer R, Michie SA, Kell D, et al. Expression of bcl-2 protein and Ki-67 nuclear proliferation antigen in benign and malignant cutaneous T-cell infiltrates. J Cutan Pathol. 1995;22(1):11-17.

60. Nielsen M, Kaestel CG, Eriksen KW, et al. Inhibition of constitutively activated Stat3 correlates with altered Bcl-2/Bax expression and induction of apoptosis in mycosis fungoides tumor cells. Leukemia. 1999;13(5):735-738.

61. Eckerdt F, Yuan J, Strebhardt K. Polo-like kinases and oncogenesis. Oncogene. 2005;24(2):267-276.

62. Ikezoe T, Yang J, Nishioka C, et al. A novel treatment strategy targeting polo-like kinase 1 in hematological malignancies. Leukemia. 2009;23(9):1564-1576.

63. Schmit TL, Zhong W, Nihal M, Ahmad N. Polo-like kinase 1 (Plk1) in non-melanoma skin cancers. Cell Cycle. 2009;8(17):2697-2702.

64. Schmit TL, Zhong W, Setaluri V, Spiegelman VS, Ahmad N. Targeted depletion of Polo-like kinase (Plk) 1 through lentiviral shRNA or a small-molecule inhibitor causes mitotic catastrophe and induction of apoptosis in human melanoma cells. $J$ Invest Dermatol. 2009;129(12):2843-2853

65. Stutz N, Nihal M, Wood GS. Polo-like kinase 1 (Plk1) in cutaneous T-cell lymphoma. Br J Dermatol. 2011;164(4):814-821.

66. Nihal M, Stutz N, Schmit T, Ahmad N, Wood GS. Polo-like kinase 1 (Plk1) is expressed by cutaneous T-cell lymphomas (CTCLs), and its downregulation promotes cell cycle arrest and apoptosis. Cell Cycle. 2011;10(8):1303-1311.

67. Schoffski P. Polo-like kinase (PLK) inhibitors in preclinical and early clinical development in oncology. Oncologist. 2009;14(6):559-570.

68. Mross K, Frost A, Steinbild S, et al. Phase I dose escalation and pharmacokinetic study of BI 2536, a novel Polo-like kinase 1 inhibitor, in patients with advanced solid tumors. J Clin Oncol. 2008;26(34):5511-5517.

69. Olmos D, Barker D, Sharma R, et al. Phase I study of GSK461364, a specific and competitive Polo-like kinase 1 inhibitor, in patients with advanced solid malignancies. Clin Cancer Res. 2011;17(10):3420-3430.

70. Jimeno A, Li J, Messersmith WA, et al. Phase I study of ON 01910.Na, a novel modulator of the Polo-like kinase 1 pathway, in adult patients with solid tumors. J Clin Oncol. 2008;26(34):5504-5510.

71. Garland LL, Taylor C, Pilkington DL, Cohen JL, Von Hoff DD. A phase I pharmacokinetic study of HMN-214, a novel oral stilbene derivative with Polo-like kinase-1-interacting properties, in patients with advanced solid tumors. Clin Cancer Res. 2006;12(17):5182-5189.

72. Chen J, Fiskus W, Eaton K, et al. Cotreatment with Bcl-2 antagonist sensitizes cutaneous T-cell lymphoma to lethal action of HDAC7Nur77-based mechanism. Blood. 2009;113(17):4038-4048.

73. Laharanne E, Oumouhou N, Bonnet F, et al. Genome-wide analysis of cutaneous T-cell lymphomas identifies three clinically relevant classes. J Invest Dermatol. 2010;130(6):1707-1718.

74. Lin WM, Lewis JM, Filler RB, et al. Characterization of the DNA copy-number genome in the blood of cutaneous T-cell lymphoma patients. J Invest Dermatol. 2012;132(1):188-197.

75. Vermeer MH, van Doorn R, Dijkman R, et al. Novel and highly recurrent chromosomal alterations in Sezary syndrome. Cancer Res. 2008;68(8):2689-2698.

76. Garzon R, Marcucci G, Croce CM. Targeting microRNAs in cancer: rationale, strategies and challenges. Nat Rev Drug Discov. 2010;9(10):775-789.

77. Ralfkiaer U, Hagedorn PH, Bangsgaard N, et al. Diagnostic microRNA profiling in cutaneous T-cell lymphoma (CTCL). Blood. 2011;118(22):5891-5900.

78. van Kester MS, Ballabio E, Benner MF, et al. miRNA expression profiling of mycosis fungoides. Mol Oncol. 2011;5(3):273-280.

79. Narducci MG, Arcelli D, Picchio MC, et al. MicroRNA profiling reveals that miR-21, miR486 and miR-214 are upregulated and involved in cell survival in Sezary syndrome. Cell Death Dis. 2011;2:e151.

80. Ballabio E, Mitchell T, van Kester MS, et al. MicroRNA expression in Sezary syndrome: identification, function, and diagnostic potential. Blood. 2010;116(7):1105-1113. 
81. Kaye FJ, Bunn PA Jr, Steinberg SM, et al. A randomized trial comparing combination electron-beam radiation and chemotherapy with topical therapy in the initial treatment of mycosis fungoides. N Engl J Med. 1989;321(26):1784-1790.

82. Herrmann JJ, Roenigk HH Jr, Hurria A, et al. Treatment of mycosis fungoides with photochemotherapy (PUVA): long-term follow-up. J Am Acad Dermatol. 1995;33(2 Pt 1):234-242.

83. Honigsmann H. Phototherapy and photochemotherapy. Semin Dermatol. 1990;9(1):84-90.

84. Querfeld C, Rosen ST, Kuzel TM, et al. Long-term follow-up of patients with early-stage cutaneous T-cell lymphoma who achieved complete remission with psoralen plus UV-A monotherapy. Arch Dermatol. 2005;141(3):305-311.

85. Trautinger F, Knobler R, Willemze R, et al. EORTC consensus recommendations for the treatment of mycosis fungoides/Sezary syndrome. Eur J Cancer. 2006;42(8):1014-1030.

86. Rosen ST, Querfeld C, Kuzel TM, Guitart J. Cutaneous T-Cell Lymphomas: A Guide for the Community Oncologist. 2nd ed. The Oncology Group, CMPMedica; 2008.

87. Zackheim HS. Treatment of patch-stage mycosis fungoides with topical corticosteroids. Dermatol Ther. 2003;16(4):283-287.

88. Zackheim HS, Kashani-Sabet M, Amin S. Topical corticosteroids for mycosis fungoides. Experience in 79 patients. Arch Dermatol. 1998;134(8):949-954.

89. Kim YH. Management with topical nitrogen mustard in mycosis fungoides. Dermatol Ther. 2003;16(4):288-298.

90. Heald P, Mehlmauer M, Martin AG, Crowley CA, Yocum RC, Reich SD. Topical bexarotene therapy for patients with refractory or persistent early-stage cutaneous T-cell lymphoma: results of the phase III clinical trial. J Am Acad Dermatol. 2003;49(5):801-815.

91. Apisarnthanarax N, Talpur R, Ward S, Ni X, Kim HW, Duvic M. Tazarotene $0.1 \%$ gel for refractory mycosis fungoides lesions: an open-label pilot study. J Am Acad Dermatol. 2004;50(4):600-607.

92. Martinez-Gonzalez MC, Verea-Hernando MM, Yebra-Pimentel MT, Del Pozo J, Mazaira M, Fonseca E. Imiquimod in mycosis fungoides. Eur J Dermatol. 2008;18(2):148-152.

93. Deeths MJ, Chapman JT, Dellavalle RP, Zeng C, Aeling JL. Treatment of patch and plaque stage mycosis fungoides with imiquimod 5\% cream. J Am Acad Dermatol. 2005;52(2):275-280.

94. Suchin KR, Junkins-Hopkins JM, Rook AH. Treatment of stage IA cutaneous T-cell lymphoma with topical application of the immune response modifier imiquimod. Arch Dermatol. 2002;138(9):1137-1139.

95. Ardigo M, Cota C, Berardesca E. Unilesional mycosis fungoides successfully treated with imiquimod. Eur $J$ Dermatol. 2006;16(4):446.

96. Urosevic M, Fujii K, Calmels B, et al. Type I IFN innate immune response to adenovirus-mediated IFN-gamma gene transfer contributes to the regression of cutaneous lymphomas. $J$ Clin Invest. 2007;117(10):2834-2846.

97. Dummer R, Eichmuller S, Gellrich S, et al. Phase II clinical trial of intratumoral application of TG1042 (adenovirus-interferon-gamma) in patients with advanced cutaneous T-cell lymphomas and multilesional cutaneous B-cell lymphomas. Mol Ther. 2010;18(6):1244-1247.

98. Jin SP, Jeon YK, Cho KH, Chung JH. Excimer laser therapy $(308 \mathrm{~nm})$ for mycosis fungoides palmaris et plantaris: a skindirected and anatomically feasible treatment. Br J Dermatol. 2010;163(3):651-653.

99. Kontos AP, Kerr HA, Malick F, Fivenson DP, Lim HW, Wong HK. 308-nm excimer laser for the treatment of lymphomatoid papulosis and stage IA mycosis fungoides. Photodermatol Photoimmunol Photomed. 2006;22(3):168-171.

100. Mori M, Campolmi P, Mavilia L, Rossi R, Cappugi P, Pimpinelli N. Monochromatic excimer light $(308 \mathrm{~nm})$ in patch-stage IA mycosis fungoides. J Am Acad Dermatol. 2004;50(6):943-945.

101. Nistico S, Costanzo A, Saraceno R, Chimenti S. Efficacy of monochromatic excimer laser radiation $(308 \mathrm{~nm})$ in the treatment of early stage mycosis fungoides. Br J Dermatol. 2004;151(4):877-879.
102. Passeron T, Zakaria W, Ostovari N, et al. Efficacy of the 308-nm excimer laser in the treatment of mycosis fungoides. Arch Dermatol. 2004;140(10):1291-1293.

103. Meisenheimer JL. Treatment of mycosis fungoides using a 308-nm excimer laser: two case studies. Dermatol Online J. 2006;12(7):11.

104. Edstrom DW, Hedblad MA. Long-term follow-up of photodynamic therapy for mycosis fungoides. Acta Derm Venereol. 2008;88(3): 288-290.

105. Coors EA, von den Driesch P. Topical photodynamic therapy for patients with therapy-resistant lesions of cutaneous T-cell lymphoma. J Am Acad Dermatol. 2004;50(3):363-367.

106. Morton CA, McKenna KE, Rhodes LE. Guidelines for topical photodynamic therapy: update. Br J Dermatol. 2008;159(6): 1245-1266.

107. Debu A, Girard C, Kluger N, Guillot B, Dereure O. Topical methyl aminolaevulinate-photodynamic therapy in erosive facial mycosis fungoides. Br J Dermatol. 2010;163(4):884-885.

108. Zane C, Venturini M, Sala R, Calzavara-Pinton P. Photodynamic therapy with methylaminolevulinate as a valuable treatment option for unilesional cutaneous T-cell lymphoma. Photodermatol Photoimmunol Photomed. 2006;22(5):254-258.

109. Hegyi J, Frey T, Arenberger P. Unilesional mycosis fungoides treated with photodynamic therapy. A case report. Acta Dermatovenerol Alp Panonica Adriat. 2008;17(2):75-78.

110. Lam M, Lee Y, Deng M, et al. Photodynamic therapy with the silicon phthalocyanine pc 4 induces apoptosis in mycosis fungoides and Sezary syndrome. Adv Hematol. 2010;2010:896161.

111. Rook AH, Wood GS, Duvic M, Vonderheid EC, Tobia A, Cabana B. A Phase II placebo-controlled study of photodynamic therapy with topical hypericin and visible light irradiation in the treatment of cutaneous T-cell lymphoma and psoriasis. J Am Acad Dermatol. 2010;63(6):984-990.

112. Suchin KR, Cucchiara AJ, Gottleib SL, et al. Treatment of cutaneous T-cell lymphoma with combined immunomodulatory therapy: a 14-year experience at a single institution. Arch Dermatol. 2002;138(8):1054-1060.

113. Raphael BA, Shin DB, Suchin KR, et al. High clinical response rate of Sezary syndrome to immunomodulatory therapies: prognostic markers of response. Arch Dermatol. 2011;147(12):1410-1415.

114. Richardson SK, McGinnis KS, Shapiro M, et al. Extracorporeal photopheresis and multimodality immunomodulatory therapy in the treatment of cutaneous T-cell lymphoma. J Cutan Med Surg. 2003; 7(Suppl 4):8-12.

115. Olsen EA, Rosen ST, Vollmer RT, et al. Interferon alfa-2a in the treatment of cutaneous T cell lymphoma. J Am Acad Dermatol. 1989;20(3):395-407.

116. Kuzel TM, Gilyon K, Springer E, et al. Interferon alfa-2a combined with phototherapy in the treatment of cutaneous T-cell lymphoma. J Natl Cancer Inst. 1990;82(3):203-207.

117. Rupoli S, Goteri G, Pulini S, et al. Long-term experience with lowdose interferon-alpha and PUVA in the management of early mycosis fungoides. Eur J Haematol. 2005;75(2):136-145.

118. Saleh MN, LeMaistre CF, Kuzel TM, et al. Antitumor activity of DAB389IL-2 fusion toxin in mycosis fungoides. J Am Acad Dermatol. 1998;39(1):63-73.

119. Prince HM, Duvic M, Martin A, et al. Phase III placebo-controlled trial of denileukin diftitox for patients with cutaneous T-cell lymphoma. $J$ Clin Oncol. 2010;28(11):1870-1877.

120. Foss F, Duvic M, Olsen EA. Predictors of complete responses with denileukin diftitox in cutaneous T-cell lymphoma. Am J Hematol. 2011;86(7):627-630.

121. Zain J, O'Connor OA. Targeting histone deacetyalses in the treatment of B- and T-cell malignancies. Invest New Drugs. 2010;28 Suppl 1: S58-S78.

122. Olsen EA, Kim YH, Kuzel TM, et al. Phase IIb multicenter trial of vorinostat in patients with persistent, progressive, or treatment refractory cutaneous T-cell lymphoma. J Clin Oncol. 2007;25(21):3109-3115. 
123. Duvic M, Talpur R, Ni X, et al. Phase 2 trial of oral vorinostat (suberoylanilide hydroxamic acid, SAHA) for refractory cutaneous T-cell lymphoma (CTCL). Blood. 2007;109(1):31-39.

124. Fantin VR, Loboda A, Paweletz CP, et al. Constitutive activation of signal transducers and activators of transcription predicts vorinostat resistance in cutaneous T-cell lymphoma. Cancer Res. 2008;68(10):3785-3794.

125. Wozniak MB, Villuendas R, Bischoff JR, et al. Vorinostat interferes with the signaling transduction pathway of T-cell receptor and synergizes with phosphoinositide-3 kinase inhibitors in cutaneous T-cell lymphoma. Haematologica. 2010;95(4):613-621.

126. Piekarz RL, Frye R, Turner M, et al. Phase II multi-institutional trial of the histone deacetylase inhibitor romidepsin as monotherapy for patients with cutaneous T-cell lymphoma. J Clin Oncol. 2009;27(32):5410-5417.

127. Whittaker SJ, Demierre MF, Kim EJ, et al. Final results from a multicenter, international, pivotal study of romidepsin in refractory cutaneous T-cell lymphoma. J Clin Oncol. 2010;28(29):4485-4491.

128. Piekarz RL, Frye AR, Wright JJ, et al. Cardiac studies in patients treated with depsipeptide, FK228, in a phase II trial for T-cell lymphoma. Clin Cancer Res. 2006;12(12):3762-3773.

129. Ellis L, Pan Y, Smyth GK, et al. Histone deacetylase inhibitor panobinostat induces clinical responses with associated alterations in gene expression profiles in cutaneous T-cell lymphoma. Clin Cancer Res. 2008;14(14):4500-4510.

130. Duvic M, Becker JC, Dalle S, et al. Phase II trial of oral panobinostat (LBH589) in patients with refractory cutaneous T-cell lymphoma (CTCL). ASH Annual Meeting Abstracts. 2008;112(11):1005.

131. Skov L, Kragballe K, Zachariae C, et al. HuMax-CD4: a fully human monoclonal anti-CD4 antibody for the treatment of psoriasis vulgaris. Arch Dermatol. 2003;139(11):1433-1439.

132. Rider DA, Havenith CE, de Ridder R, et al. A human CD4 monoclonal antibody for the treatment of T-cell lymphoma combines inhibition of T-cell signaling by a dual mechanism with potent Fc-dependent effector activity. Cancer Res. 2007;67(20): 9945-9953.

133. Kim YH, Duvic M, Obitz E, et al. Clinical efficacy of zanolimumab (HuMax-CD4): two phase 2 studies in refractory cutaneous T-cell lymphoma. Blood. 2007;109(11):4655-4662.

134. Dyer MJ, Hale G, Hayhoe FG, Waldmann H. Effects of Campath-1 antibodies in vivo in patients with lymphoid malignancies: influence of antibody isotype. Blood. 1989;73(6):1431-1439.

135. Greenwood J, Clark M, Waldmann H. Structural motifs involved in human IgG antibody effector functions. Eur J Immunol. 1993;23(5):1098-1104.

136. Heit W, Bunjes D, Wiesneth M, et al. Ex vivo T-cell depletion with the monoclonal antibody Campath-1 plus human complement effectively prevents acute graft-versus-host disease in allogeneic bone marrow transplantation. Br J Haematol. 1986;64(3):479-486.

137. Rowan W, Tite J, Topley P, Brett SJ. Cross-linking of the Campath-1 antigen (CD52) mediates growth inhibition in human B- and T-lymphoma cell lines, and subsequent emergence of CD52-deficient cells. Immunology. 1998;95(3):427-436.

138. Lundin J, Hagberg H, Repp R, et al. Phase 2 study of alemtuzumab (anti-CD52 monoclonal antibody) in patients with advanced mycosis fungoides/Sezary syndrome. Blood. 2003;101(11):4267-4272.

139. Querfeld C, Mehta N, Rosen ST, et al. Alemtuzumab for relapsed and refractory erythrodermic cutaneous T-cell lymphoma: a single institution experience from the Robert H. Lurie Comprehensive Cancer Center. Leuk Lymphoma. 2009;50(12):1969-1976.

140. Lenihan DJ, Alencar AJ, Yang D, Kurzrock R, Keating MJ, Duvic M. Cardiac toxicity of alemtuzumab in patients with mycosis fungoides/ Sezary syndrome. Blood. 2004;104(3):655-658.

141. Lundin J, Kennedy B, Dearden C, Dyer MJ, Osterborg A. No cardiac toxicity associated with alemtuzumab therapy for mycosis fungoides/ Sezary syndrome. Blood. 2005;105(10):4148-4149.
142. Marchi E, Alinari L, Tani M, et al. Gemcitabine as frontline treatment for cutaneous T-cell lymphoma: phase II study of 32 patients. Cancer. 2005;104(11):2437-2441.

143. Wollina U, Dummer R, Brockmeyer NH, et al. Multicenter study of pegylated liposomal doxorubicin in patients with cutaneous T-cell lymphoma. Cancer. 2003;98(5):993-1001.

144. Duvic M, Talpur R, Wen S, Kurzrock R, David CL, Apisarnthanarax N. Phase II evaluation of gemcitabine monotherapy for cutaneous T-cell lymphoma. Clin Lymphoma Myeloma. 2006;7(1):51-58.

145. Sirotnak FM, DeGraw JI, Moccio DM, Samuels LL, Goutas LJ. New folate analogs of the 10-deaza-aminopterin series. Basis for structural design and biochemical and pharmacologic properties. Cancer Chemother Pharmacol. 1984;12(1):18-25.

146. DeGraw JI, Colwell WT, Piper JR, Sirotnak FM. Synthesis and antitumor activity of 10-propargyl-10-deazaaminopterin. J Med Chem. 1993;36(15):2228-2231.

147. Wang ES, O’Connor O, She Y, Zelenetz AD, Sirotnak FM, Moore MA. Activity of a novel anti-folate (PDX, 10-propargyl 10-deazaaminopterin) against human lymphoma is superior to methotrexate and correlates with tumor RFC-1 gene expression. Leuk Lymphoma. 2003;44(6):1027-1035.

148. Horwitz SM, Kim YH, Foss FM, et al. Identification of an active, well-tolerated dose of pralatrexate in patients with relapsed or refractory cutaneous T-cell lymphoma (CTCL): final results of a multicenter dose-finding study. ASH Annual Meeting Abstracts. 2010;116(21):2800.

149. Foss FM, Horwitz SM, Pinter-Brown L, et al. Pralatrexate is an effective treatment for heavily pretreated patients with relapsed/refractory transformed mycosis fungoides (tMF). ASHAnnual Meeting Abstracts. 2010;116(21):1762.

150. O'Connor OA, Pro B, Pinter-Brown L, et al. Pralatrexate in patients with relapsed or refractory peripheral T-cell lymphoma: results from the pivotal PROPEL study. J Clin Oncol. 2011;29(9):1182-1189.

151. Marchi E, Paoluzzi L, Scotto L, et al. Pralatrexate is synergistic with the proteasome inhibitor bortezomib in in vitro and in vivo models of T-cell lymphoid malignancies. Clin Cancer Res. 2010;16(14):3648-3658.

152. Olavarria E, Child F, Woolford A, et al. T-cell depletion and autologous stem cell transplantation in the management of tumour stage mycosis fungoides with peripheral blood involvement. Br J Haematol. 2001;114(3):624-631.

153. Russell-Jones R, Child F, Olavarria E, Whittaker S, Spittle M, Apperley J. Autologous peripheral blood stem cell transplantation in tumor-stage mycosis fungoides: predictors of disease-free survival. Ann NY Acad Sci. 2001;941:147-154.

154. Baron F, Storb R. Allogeneic hematopoietic cell transplantation following nonmyeloablative conditioning as treatment for hematologic malignancies and inherited blood disorders. Mol Ther. 2006;13(1):26-41.

155. Duarte RF, Canals C, Onida F, et al. Allogeneic hematopoietic cell transplantation for patients with mycosis fungoides and Sezary syndrome: a retrospective analysis of the Lymphoma Working Party of the European Group for Blood and Marrow Transplantation. J Clin Oncol. 2010;28(29):4492-4499.

156. Duvic M, Donato M, Dabaja B, et al. Total skin electron beam and non-myeloablative allogeneic hematopoietic stem-cell transplantation in advanced mycosis fungoides and Sezary syndrome. J Clin Oncol. 2010;28(14):2365-2372.

157. Fukushima T, Horio K, Matsuo E, et al. Successful cord blood transplantation for mycosis fungoides. Int J Hematol. 2008;88(5):596-598.

158. Tsuji H, Wada T, Murakami M, et al. Two cases of mycosis fungoides treated by reduced-intensity cord blood transplantation. J Dermatol. 2010;37(12):1040-1045.

159. List A, Kurtin S, Roe DJ, et al. Efficacy of lenalidomide in myelodysplastic syndromes. N Engl J Med. 2005;352(6):549-557.

160. Richardson PG, Schlossman RL, Weller E, et al. Immunomodulatory drug CC-5013 overcomes drug resistance and is well tolerated in patients with relapsed multiple myeloma. Blood. 2002;100(9):3063-3067. 
161. Bartlett JB, Dredge K, Dalgleish AG. The evolution of thalidomide and its IMiD derivatives as anticancer agents. Nat Rev Cancer. 2004;4(4):314-322.

162. Querfeld C, Rosen ST, Guitart J, et al. Phase II multicenter trial of lenalidomide: clinical and immunomodulatory effects in patients with CTCL. ASH Annual Meeting Abstracts. 2011;118(21):1638.

163. Krieg AM. Development of TLR9 agonists for cancer therapy. J Clin Invest. 2007;117(5):1184-1194.

164. Kim YH, Girardi M, Duvic M, et al. Phase I trial of a Toll-like receptor 9 agonist, PF-3512676 (CPG 7909), in patients with treatmentrefractory, cutaneous T-cell lymphoma. J Am Acad Dermatol. 2010;63(6):975-983.

165. Juvekar A, Manna S, Ramaswami S, et al. Bortezomib induces nuclear translocation of IkappaBalpha resulting in gene-specific suppression of NF-kappaB - dependent transcription and induction of apoptosis in CTCL. Mol Cancer Res. 2011;9(2):183-194.

166. Palombella VJ, Rando OJ, Goldberg AL, Maniatis T. The ubiquitinproteasome pathway is required for processing the NF-kappa B1 precursor protein and the activation of NF-kappa B. Cell. 1994;78(5):773-785.
167. Sors A, Jean-Louis F, Pellet C, et al. Down-regulating constitutive activation of the NF-kappaB canonical pathway overcomes the resistance of cutaneous T-cell lymphoma to apoptosis. Blood. 2006;107(6):2354-2363.

168. Zinzani PL, Musuraca G, Tani M, et al. Phase II trial of proteasome inhibitor bortezomib in patients with relapsed or refractory cutaneous T-cell lymphoma. J Clin Oncol. 2007;25(27):4293-4297.

169. Ito A, Ishida $\mathrm{T}$, Yano H, et al. Defucosylated anti-CCR4 monoclonal antibody exercises potent ADCC-mediated antitumor effect in the novel tumor-bearing humanized NOD/Shi-scid, IL-2Rgamma(null) mouse model. Cancer Immunol Immunother. 2009;58(8):1195-1206.

170. Yamamoto K, Utsunomiya A, Tobinai K, et al. Phase I study of KW-0761, a defucosylated humanized anti-CCR4 antibody, in relapsed patients with adult T-cell leukemia-lymphoma and peripheral T-cell lymphoma. J Clin Oncol. 2010;28(9):1591-1598.

171. Sirotnak FM, DeGraw JI, Schmid FA, Goutas LJ, Moccio DM. New folate analogs of the 10-deaza-aminopterin series. Further evidence for markedly increased antitumor efficacy compared with methotrexate in ascitic and solid murine tumor models. Cancer Chemother Pharmacol. 1984;12(1):26-30.

\section{Publish your work in this journal}

Cancer Management and Research is an international, peer-reviewed open access journal focusing on cancer research and the optimal use of preventative and integrated treatment interventions to achieve improved outcomes, enhanced survival and quality of life for the cancer patient The journal welcomes original research, clinical \& epidemiological

\section{Dovepress}

studies, reviews \& evaluations, guidelines, expert opinion \& commentary, case reports \& extended reports. The manuscript management system is completely online and includes a very quick and fair peerreview system, which is all easy to use. Visit http://www.dovepress.com/ testimonials.php to read real quotes from published authors. 